\title{
Um drama vaudevilesco: o lugar do cínico Robert Macaire na cena teatral carioca de meados do século XIX
}

A vaudevillesque drama: the place of the cynical
Robert Macaire in Rio's theatrical scene in the mid-
nineteenth century

Bruna Grasiela Silva Rondinelli ${ }^{1}$

Danielle Crepaldi Carvalho ${ }^{2}$ 


\section{Resumo}

Este artigo toma como objeto de análise a circulação da peça francesa $A$ Estalagem dos Trampolineiros, no Rio de Janeiro de meados do XIX. Escrita em 1823, segundo os cânones do Melodrama, para ser representada no Bulevar do Crime, a obra gerou celeuma quando os atores Lemaître e Firmin modificaram o jogo de cena inerente ao gênero, transformando os bandidos Robert Macaire e Bertrand em tipos cômicos de grande apelo público. Analisamos a recepção brasileira da obra, buscando observar os efeitos provocados pelos deslocamentos que ela realiza nas convenções já estabilizadas, procurando, assim, acenar para a complexidade da cena teatral do período.

Palavras-chave: Teatro; encenação; Robert Macaire; A Estalagem dos Trampolineiros; século XIX

\section{Abstract}

This article analyzes the circulation of the French theater play L'Auberge des Adrets, in the Rio de Janeiro of the midnineteenth century. Written accordingly to the canons of the Melodrama, in 1823, to be played in the Boulevard du Crime, the play generated a vast public disturbance as the actors Lemaître and Firmin altered the staging commonly applied for the genre, turning the bandits they both portrayed into comic types of great public appeal. The article deals with the Brazilian reception of the play; in order to observe the effects of the displacements it performs in the stabilized conventions of the Melodrama, therefore aiming to highlight the complexity of the theatrical scene of that time.

Keywords: Theater; staging; Robert Macaire; L'Auberge des Adrets; XIX ${ }^{\text {th }}$ century 


\section{Introdução}

A narrativa da história do teatro brasileiro foi sistematizada pelas histórias da literatura e histórias teatrais nacionais. As histórias literárias trataram a dramaturgia como um apêndice (Faria, 2010), estudando-a de acordo com as características das escolas literárias (romantismo, realismo, naturalismo etc.). As primeiras histórias do teatro brasileiro que se dedicaram à construção de uma narrativa que ordenasse as manifestações teatrais realizadas em solo brasílico começaram a vir à luz nos primeiros anos do século XX. Essas obras históricas de longa duração narram acontecimentos decisivos, listam o repertório e os artistas que se destacaram nos palcos, e apresentam a trajetória dos edifícios que acomodaram as salas de espetáculos de maior expressão.

Para narrar a história do teatro brasileiro, a crítica literária e teatral de meados do século XX adotou a divisão em movimentos literários, a afiliação ao nacionalismo crítico e a busca do moderno (Guinsburg, Patriota, 2012), e referenciais que, na maioria das vezes, reduziram as manifestações teatrais ao eixo Rio de Janeiro - São Paulo, e relegaram a um segundo plano as peças mais preocupadas com a arte do espetáculo que com a qualidade literária do texto, como os melodramas e as operetas. Procedimentos que formataram a narrativa histórica do teatro brasileiro em "lacunas e séries - vazios e repetições de natureza recorrente" (Brandão, 2010, p. 375).

A compartimentação da produção teatral brasileira segundo os eixos supracitados dialogava com um amplo projeto cultural, do qual tomavam parte vários segmentos das Ciências Humanas: o cinema, através da figura de, notadamente, Paulo Emílio Salles Gomes (Morettin, 2014); o teatro, por meio de Décio de Almeida Prado; a literatura, por meio de Antonio Candido de Mello e Souza. Embasava o projeto um objetivo legítimo: revelar o Brasil, naquilo que nele haveria de intrinsecamente nacional. Daí a Paulo Emílio voltar-se ao cinema brasileiro "como uma realidade autônoma", recortando-o do contexto externo, atribuindo o rótulo de "bela época" ao momento em que mais se produziu filmes de ficção nacionais (Morettin, 2014, p. 557); daí a Décio de Almeida Prado e a Antonio Candido voltarem uma visada teleológica aos seus campos de estudo; tomando o teatro moderno e a literatura modernista como pontos culminantes na evolução das respectivas séries, e valorando cada escola literária ou teatral no que elas possuíam de brasilidade ${ }^{3}$. (Prado, 1999; Candido, 1975; Candido, Castelo, 1976).

Hoje, as escolhas metodológicas da pesquisa histórica são outras. Volta-se à abordagem vertical de contextos específicos - em contraposição às análises de largos panoramas, procedimento outrora usual -, procurando perceber esses campos

\footnotetext{
3 Abel Barros Baptista estende-se a respeito de Antonio Candido. Segundo o crítico, Candido foi um "dos primeiros frutos da jovem USP" (Baptista, 2005, p. 46), onde se graduou e lecionou até se aposentar, em 1978. Batista pondera que as Ciências Sociais tiveram peso determinante na Universidade, peso que fez com que a constituição do Brasil se transformasse em objeto acadêmico, o que culminou com a mudança do nome da instituição de "Faculdade de Filosofia, Ciências e Letras" para "Faculdade de Filosofia, Letras e Ciências Humanas" (Baptista, 2005, p. 45). Candido, juntamente com um grupo de estudantes da USP, fundou a revista Clima, na qual ele redigia a crítica literária. A revista objetivava, de acordo com Baptista, irradiar, a partir de São Paulo, "um clima de interesse e de ventilação intelectual" (Baptista, 2005, p. 45), o que a aproximava do objetivo dos modernistas de 1920. Neste contexto, o próprio escritor modernista Mário de Andrade é convidado para escrever um texto de apresentação do periódico, o que deixa explícito o intento de aproximar da Universidade o programa modernista (Baptista, 2005, p. 46). A Universidade de São Paulo teria tido, portanto, ímpar importância no estabelecimento do cânone literário, e o fizera através da exclusão do passado e da afirmação do "brasileiro" como o elemento por excelência de configuração das obras: "A construção do cânone assenta num gesto de exclusão do passado, modernista porque em nome do novo, mas também nacionalista por via da hipálage que transfere o epíteto 'brasileiro' do processo de estabelecimento para o cânone estabelecido" (Baptista, 2005, p. 55).
} 
artísticos segundo a relação que eles estabelecem com a história. (Morettin, 2014; Bernardet, 2004). Especificamente no que toca ao estudo do teatro, tenta-se estabelecer diálogos entre a literatura dramática, a arte da cena e os mecanismos sociais e econômicos que engendram a atividade teatral. Nesse sentido, focaliza-se a recepção crítica coetânea das obras, a economia dos espetáculos, a atuação da censura (Souza, 2002), o mapeamento da circulação transnacional de repertório dramático e artistas (Junqueira, 2015).

Nosso objeto de análise neste artigo toma parte de modo privilegiado neste contexto. A peça L'Auberge des Adrets (1823), de autoria de Antier, Saint-Amand e Polyanthe, foi escrita segundo os cânones do melodrama, gênero erigido na Paris pós-revolução francesa. A inserção da obra no interior de uma tipologia obedecia a fins específicos. Comerciais, já que ela foi formatada ao Théâtre de l'Ambigu-Comique, uma das salas de exibição do Bulevar do Crime, área de Paris destinada à apresentação de espetáculos "populares" - por oposição a "eruditos", considerados, portanto, exemplares inferiores de arte, segundo a hierarquia clássica que então se aplicava. E morais, considerando-se o papel que os melodramaturgos se autoatribuíam, de impor, por meio dos textos, balizas à conduta social - o gênero melodramático funcionava, assim, como sucedâneo da Igreja, instituição que fora, por excelência, vítima dos revolucionários de 1789 (Thomasseau, 2009).

Caberia aos melodramas (também denominados "dramas", à época) a organização da turbilhonante cena social do período. As obras pertencentes aos seus cânones eram balizadas por regras definidas. Competia aos autores a construção de personagens facilmente discerníveis pelo público, daí a bondade ou maldade dos caracteres se exibirem em seus trajes e gestuais. A dicotomia respeitava fins educativos. $O$ melodrama reproduzia a lógica cristã da existência: elevando às alturas da felicidade os bons e punindo exemplarmente os maus.

Neste contexto convencional imiscui-se Frédérick Lemaître, figura fundamental da cena artística do período. Contratado para desempenhar o papel do vilânico Robert Macaire - que abandonara a esposa e a prole, obrigando a consorte a purgar pelos crimes que ele cometera - o jovem ator decide construir, visualmente, uma personagem marcada pela ambiguidade: mistura a bandagem negra, comum aos vilões, às roupas coloridas e rasgadas, à bengala senhorial, à caixa de rapé e aos sapatos de baile. E ao fazê-lo, desloca aquela personagem-tipo do lugar que ela ocupava na constelação do gênero, borrando, por extensão, os sentidos já consolidados para as personagens de sua sorte. Em cena, os grunhidos de Robert Macaire incitavam no público o riso de aprovação, indo, portanto, na contracorrente do que se esperava do gênero melodramático - fato que motivou uma forte reação por parte da censura.

Este artigo propõe-se a pensar o âmbito da encenação como espaço fundamental para a construção dos sentidos da peça teatral. Debruçaremo-nos sobre o texto de L'Auberge des Adrets considerando primeiro seu contexto original de encenação, para, em seguida, analisarmos as diferentes abordagens que teve a peça, no Rio de Janeiro de fins de 1830 a fins de 1850 - as quais transcendem as fronteiras estanques estabelecidas pela história tradicional do teatro brasileiro. Tal percurso demonstrará o quanto a pesquisa histórica voltada à observação de contextos específicos pode contribuir para o burilamento da reflexão sobre a história do teatro do século XIX. 


\section{L'Auberge des Adrets em Paris: deslocamento e censura}

L'Auberge des Adrets foi redigido por seus autores de acordo com a ética burguesa do melodrama de respeito à autoridade de Deus, do Estado, da família, da propriedade e da hierarquia social. Sendo assim, o casamento e a sucessão de bens familiares são temas caros aos autores da peça. O casamento, concebido como um contrato firmado entre as partes interessadas, isto é, os pais dos jovens consortes, previa um dote e regularizava a posse da herança.

Desse modo, não é à toa que a peça se inicia com os preparativos do casamento de Charles e Clementine. Esta possui um dote de 12 mil francos e o rapaz é o herdeiro da estalagem pertencente a seu pai, o Sr. Dumont. Eis que a providência divina faz com que, no mesmo dia, cheguem à estalagem novos hóspedes que impulsionam as ações do enredo: Marie, uma mulher miserável, Bertrand e Rémond, dois fugitivos da prisão que viajam sob nomes falsos e são, na verdade, Jacques Strobe e Robert Macaire. A partir de então, duas intrigas se desenvolvem e se entrelaçam. Os bandidos tentam assassinar o pai da noiva, o Sr. Germeuil, para subtraírem o dote que este trazia consigo. Marie é acusada erradamente pelo crime, mas, logo, Robert Macaire e Bertrand são desmascarados.

Simultaneamente, uma intriga familiar complexa toma forma: Marie se revela a mãe do noivo, abandonada após o nascimento do filho pelo esposo, Robert Macaire, morto no final da peça por seu comparsa. Antes de dar o último suspiro, o criminoso pede perdão pelas suas faltas. A identidade do verdadeiro pai de Charles não é, no entanto, revelada às outras personagens, mantendo-se em segredo: "CARLOS (em vias de se lançar, involuntariamente, sobre Raimundo, denunciando-se) - É o meu... / MARIA (com vivacidade) - Silêncio! Ele já não está mais aqui" (Antier, Saint-Amand, Polyanthe, 1823, p. 43). ${ }^{4}$ Após todo o sofrimento que Robert Macaire causara a sua família, desmoralizando-a perante a sociedade, Marie, com este ato final, impede que a condição social do filho seja manchada com a revelação de pertencimento a uma estirpe criminosa.

A galeria de personagens de L'Auberge des Adrets segue a convenção do melodrama. Além da figura paterna, da mãe virtuosa, do vilão sem escrúpulos e do casal de enamorados, também se faz presente a personagem cômica (niais), que ameniza os momentos patéticos com tiradas cômicas e ações risíveis. Pierre, funcionário da estalagem, desempenha o tipo, um misto de bobo e ingênuo, cuja linguagem é repleta de $a_{\text {grgots }}{ }^{5}$. Assim como os tipos, o enredo da peça também se alinha à poética melodramática. A estrutura familiar é abalada por infortúnios ocasionados pelo embate entre o Bem e o Mal. Contudo, após os momentos de tensão, nos quais os vilões parecem se safar impunemente, os nós da trama se deslindam com o reconhecimento e a retribuição: os verdadeiros culpados são punidos (Robert Macaire é assassinado pelo comparsa, ao passo que este é preso) e os bons são recompensados. A família retoma a estrutura harmônica, outrora abalada pela corrupção engendrada pelos vícios mundanos.

4 No original : « CHARLES (veut s'élancer sur Rémond, entraîné malgré lui, il va se découvrir) - C'est mon... / MARIE (vivement) - Silence ! II n'est déjà plus. » (Tradução das autoras).

5 Denominação francesa utilizada para se referir ao jargão falado pelos ladrões e marginais. Por extensão de sentido, refere-se à língua particular falada por pessoas que exercem uma mesma atividade. Cf. Houaiss Eletrônico. 
O melodrama, herdeiro da estética do efeito dos dramas larmoyants ${ }^{6}$ do século XVIII, adotou como expediente indispensável dos finais dos atos as ações e frases carregadas de emoções. Os momentos patéticos amplificam os sentimentos e a tensão do clímax, provocando a forte sensibilização e a manutenção da atenção da plateia. Em L'Auberge des Adrets, é exemplar a cena XVIII, do ato segundo, quando Marie descobre que Rémond era, na verdade, o esposo que a abandonara anos antes na miséria: "MARIA (o reconhecendo) - Deus! É ele! (ela cai desmaiada)" (Antier, Saint -Amand, Polyanthe, 1823, p. 31).7

Os momentos patéticos eram acompanhados de música instrumental, desempenhada pela orquestra fixa dos teatros. Nesse aspecto, melodrama e ópera não se distavam. As óperas românticas, de enredos folhetinescos, são recheadas de momentos emotivos, principalmente se considerarmos as árias de elevado lirismo, trechos cantados a solo com acompanhamento instrumental, nos quais a personagem canta seus lamentos. Se melodrama e drama romântico, por um lado, guardam características estéticas próprias, por outro lado, não se encontravam tão distantes assim. De fato, a linha que separava o que hoje conhecemos por drama romântico do melodrama é mais tênue do que promulgou ser a crítica literária baseada em critérios hierarquizantes de gêneros dramáticos. Por exemplo, o drama Hernani (1830), do canonizado Victor Hugo, mescla entre seus versos motivos de melodrama, tais como esconderijos, punhais e cenas de reconhecimento.

Para além das questões formais do texto dramático, é digno de nota que os dramas Le Roi s'Amuse (1832), Marion de Lorme (1833), Lucrèce Borgia (1833) e Marie Tudor (1833), do mesmo célebre dramaturgo, foram criados no Théâtre de la Porte Saint-Martin, casa de espetáculos do Bulevar do Crime (Naugrette, 2001), concorrente do Théâtre de l'Ambigu-Comique, onde estreou L'Auberge des Adrets em 1823 . 0 que tentamos sinalizar é que, tanto em termos de composição do texto dramático, quanto de condições da mise en scène, no contexto de criação e reprises de L'Auberge des Adrets, na primeira metade do século XIX, a divisão dos gêneros dramáticos não era tão evidente, o que revela uma complexidade dos palcos além do que propôs a historiografia literária e teatral baseada na hierarquização das poéticas dramáticas.

O texto de L'Auberge des Adrets, ao se inscrever na tradição do melodrama, previa uma relação com o espectador: emocioná-lo com os momentos patéticos e educá-lo segundo os preceitos da ética burguesa. No entanto, a montagem recriadora dos atores Lemaître e Firmin no Théâtre de l'Ambigu-Comique, em 1823, subverteu os códigos cênicos e a moral do melodrama, transformando a personagem Robert Macaire de um vilão a um vagabundo cínico e sem escrúpulos. Lemaître abandonou a vestimenta preta e o conjunto de mímicas que identificavam o vilão, pisando o palco com o cabelo mal penteado, uma bandagem negra que cobria um dos olhos, trajes coloridos e puídos. $O$ ator parodiou as convenções cênicas do melodrama, como o jogo pantomímico e a impostação da voz que caracterizavam os vilões, conferindo à personagem um andar aristocrático. De vilão, Robert Macaire se transformou em um bandido meio dândi meio bufão cínico. Em seu livro de memórias, Lemaître rememo-

6 Peças que visavam à catarse por meio de momentos patéticos que levavam as plateias às lágrimas (Thomasseau, 1995, p. 109-114).

7 No original: « MARIE (le reconnaissant) - Dieu ! C'est lui ! (elle tombe évanouie). » (Tradução das autoras). 
rou uma noite de ensaios da peça, momento em que percebeu quão engraçado seria Robert Macaire se às suas ações e falas fosse conferido um tom cômico:

[...] quando numa noite, virando e revirando as páginas de meu manuscrito, comecei a achar engraçadas todas as situações e todas as frases dos papéis de Robert Macaire e de Bertrand, se elas fossem interpretadas comicamente (Lemaître, 1880, p. 84). ${ }^{8}$

A estrutura do melodrama tradicional foi subvertida pela atuação paródica e as improvisações verbais e gestuais de Lemaître. O deslocamento ocasionado pela ruptura com as convenções melodramáticas reelaborou os sentidos de L'Auberge des Adrets. A peça estendeu sua relação com o espectador, passando a diverti-lo com as bufonarias dos dois bandidos. A plateia não temia mais o vilão, pelo contrário, simpatizava-se com suas ações moralmente condenáveis. O tipo cínico criado pela interpretação de Lemaître colocava em xeque os valores morais originais do melodrama, ao contestar a ordem monárquica e burguesa (Bara, 2010).

O riso subversivo de Robert Macaire logo atraiu a atenção da censura francesa, temerosa de desordens sociais nos teatros, já que estes representavam, no século XIX, espaços públicos privilegiados de debates e manifestações políticas. Em 2 de abril de 1824, após mais de noventa exibições, a peça foi proibida de subir novamente ao palco (Krakovitch, 1987), o que não culminou, no entanto, na extinção da personagem. Robert Macaire reaparecia nos palcos parisienses nos momentos de relaxamento da censura, como ocorreu em 1832, quando uma nova versão de L'Auberge des Adrets foi montada no Théâtre de la Porte Saint-Martin, e em 1834, com a estreia do vaudeville Robert Macaire no Folies-Dramatiques, teatro também localizado no Bulevar do Crime, reduto do teatro de cunho popular.

Em 1835, com o endurecimento da censura teatral francesa, novas montagens de L'Auberge des Adrets e Robert Macaire foram proibidas. A personagem foi banida dos teatros de Paris, pois simbolizava a subversão da ordem moral, política e social, o que amedrontava a monarquia de Louis-Philippe (Krakovitch, 1987). Apesar da interdição nos palcos, Robert Macaire, relido como símbolo de derrisão e cinismo, inspirou produções literárias e artísticas, como o melodrama cômico em dois atos $L a$ Fille de Robert Macaire (1835), de Julien de Mallian e Barthélemy, e a célebre série de litografias assinadas por Honoré Daumier, intitulada Les Cent et un Robert Macaire, organizada em dois volumes em 1839.

Nascido da força cômica do jogo interpretativo de um ator, que recriou o texto dramático de L'Auberge des Adrets, Robert Macaire, deslocando-se de um vilão a um vagabundo cínico e inescrupuloso, tornou-se uma personagem mítica, parte integrante do imaginário social e literário do século XIX, não apenas na França, mas também no Brasil. No Rio de Janeiro, Robert Macaire deixou lembranças nos espectadores que aplaudiram as montagens realizadas nos teatros da Corte, incluindo o Imperador D. Pedro II que, em viagem à Cannes em 1887, ao passar por uma estalagem denominada Auberge des Adrets, “lembrou-se de ter visto representar L'Auberge des Adrets há bons 40 anos, no Rio de Janeiro, e tinha presente o papel desempenhado na comédia pelo tipo legendário de Robert Macaire" (Gazetilha, 1888, p. 2). 8 No original: « lorsqu'un soir, en tournant et retournant les pages de mon manuscrit, je me mis à trouver excessivement bouffonnes toutes les situations et toutes
les phrases des rôles de Robert Macaire et de Bertrand, si elles étaient prises au comique. » (Tradução das autoras). 


\section{Robert Macaire(s) no Rio de Janeiro de 1839 a 1858}

O público carioca dos anos de 1830-1850 tomou contato com uma sorte considerável de Robert Macaires, levados à cena por companhias francesas e brasileiras, seja em nosso idioma, seja no original francês. L'Auberge des Adrets foi encenado pela primeira vez nessas paragens em agosto de 1839, sob o título de Os Fugitivos das Prisões de Leão, "drama em três atos" escolhido pela atriz Maria Soares do Nascimento para a realização de seu benefício, no Teatro de S. Januário. A artista portuguesa vivia no Rio de Janeiro desde 1829, ano em que aportara na cidade a trupe que comporia a "Companhia Dramática do Teatro Imperial de São Pedro de Alcântara" (Sousa Bastos, 1908, p. 360).

A relevância da missão artística a que tal grupo se autoatribuía foi, aparentemente, decisiva para a escolha da peça e para o viés que teve a encenação. A atriz chega a ir a público no intuito de sublinhar a força moralizante da obra, e a relevância daquela encenação visando-se a preencher "o fim universal da arte dramática": de "ensinar por meio do exemplo o horror ao vício, aos crimes, e a execração aos infames" (Teatros, 1839, p. 3). Neste sentido, classifica as personagens dos dois bandidos - as quais a tradução em português dá destaque, a contrapelo do original francês - como "dois desgraçados a quem a licença do berço, e depois os remorsos não deixam tranquilos, [...] eles vagueiam como o amaldiçoado, e em sua passagem deixam indícios do sangue, e de horror!" (Teatros, 1839, p. 3). A dubiedade de que a encenação da peça originalmente a dotara é deixada de lado pela atriz, segundo cuja leitura Macaire e Bertrand eram dois sujeitos lúgubres, vilães típicos a quem a má-criação transformara em sucedâneos do diabo, a espalharem a destruição por onde passavam.

Um ano mais tarde, o mesmo $S$. Januário veria uma peça com outros contornos, encenada desta vez em francês, pelas mãos da "Compagnie Dramatique Française" de M. Ernest Gervaise. "L'Auberge des Adrets", "drame comique en 3 actes", parece ter recuperado, no Rio, o poder disruptivo da encenação de Lemaître e Firmin: o gênero no qual o anúncio a inscreve remete ao desenho ambíguo que os dois atores franceses deram aos seus caracteres; característica sublinhada pelo folhetinista do Diário do Rio de Janeiro, na resenha que faz do espetáculo: "Ah! M. Moreau, nunca lhe perdoaremos o seu procedimento nessa noite de quarta-feira. Pedir-nos indulgência e fazer-nos rir como loucos!" (L'Auberge des Adrets, 1840, p. 4). A ausência de censura dramática em solo brasileiro permitiu ao encenador francês investir no tom cômico que garantira a notoriedade - e a proibição - da peça na França.

O sucesso de público de L'Auberge des Adrets em sua terra natal fomentou a produção de várias derivações da obra. Uma das mais célebres foi eternizada pelo cineasta Marcel Carné no filme O Boulevard do Crime (1945). Trata-se de uma redução em dois atos da peça ${ }^{9}$, de 1832, profundamente influenciada pela cena vaudevilesca do período: nela, além de Macaire e Bertrand entoarem coplas incensando a vida desregrada que levavam, ambos rompem com a quarta-parede inerente ao gênero melodramático, utilizando o espaço da plateia como palco da cena de perseguição que fecha o espetáculo (MM. Benjamin, Saint-Amand, Paulyanthe 1832).

9 A versão de 1832 possui, na verdade, os três atos do original de 1823. No entanto, além de o original de 1823 haver recebido alterações sensíveis, o terceiro ato da nova versão consta como opcional. Cf. Mm. Benjamin, Saint-Amant; Paulyanthe, 1832. 
Ao que apuramos, esta versão foi encenada na Capital Federal em duas ocasiões, por duas companhias francesas, em língua francesa: pela "Compagnie Lyrique Française" (no S. Januário, em 1849), e pela "Ancienne Compagnie Française" (no S. Francisco, em 1854). A classificação de ambas como "dramas" recupera uma característica fundamental ao vaudeville, gênero ao qual a música e o riso não se dissociavam do empenho moralizante. Influenciados pela cena erudita, os gêneros cômico-musicados comportam características da comédia, do drama e da ópera - encaixando-se num entre-lugar que, embora apraza à nossa cena contemporânea, à época denotava deficiência dramatúrgica, inserindo-se esses exemplares teatrais numa categoria inferior no que tocava à hierarquia dos gêneros. Por isso, quem sabe, a resistência do ator brasileiro João Caetano - então, um célebre intérprete de personagens trágicas e dramáticas - frente a outra derivação do melodrama de L'Auberge des Adrets: o drama burlesco Robert Macaire (estreado em Paris em 1834).

O insuspeitado sucesso alcançado, na França, pela obra de que nos ocupamos - conquistado graças à ruptura com os paradigmas clássicos do melodrama (Thomasseau, 2009) - , fomenta a produção desta simbólica sequência da obra. A "pièce en quatre actes et en six tableaux" Robert Macaire, escrita em coautoria por MM. Saint -Amand, Antier e Frédérick Lemaître, metaforiza o caráter redivivo de Robert Macaire. Herói sem caráter, de imorredoura presença no imaginário do público, Macaire pisa a cena vindo de escapar miraculosamente à morte - proprietário de uma companhia de seguros que serve de fachada ao engendramento de seus embustes - , para, após uma nova sucessão de crimes, ele e seu comparsa Bertrand empreenderem a fuga das autoridades a bordo de um balão.

João Caetano incumbe-se do papel do célebre valdevinos, na ocasião da estreia de Robert Macaire nos palcos cariocas, em 1846. Responsável pela companhia que se apresentava no Teatro São Francisco, o ator não economiza na encenação, conformando-a à dimensão "ocular" (o termo é de Théophile Gautier) primordial a gêneros teatrais populares - os quais buscavam seduzir o público por meio da exuberância da encenação (Thomasseau, 2009, p. 24): "Todo o vestuário e as demais decorações são em grande parte novas e a caráter" (Teatro, 1846a, p. 2), sublinha o anúncio do espetáculo. Todavia, o anúncio da segunda das três récitas de Robert Macaire opera um deslocamento no que toca ao seu gênero, denominando-o "interessante e aplaudido drama em 4 atos e 6 quadros" (Teatro, 1846b, p. 2). ${ }^{10}$

Passa-se, assim, ao largo da dimensão irreverente da peça - elemento, contudo, não deixado de lado por João Caetano no momento da encenação, como nos demonstra um inusitado crítico seu, o jovem escritor Álvares de Azevedo: "nós [...] que soltamos boas gargalhadas ante [...] Robert Macaire, não podemos deixar de lamentar que ele [João Caetano] desdenhe a máscara da comédia" (Azevedo, 1862, p. 152). Caetano não era alheio à hierarquia a que se submetiam os gêneros teatrais, tributária da Poética de Aristóteles - hierarquia que tomava a tragédia como o exemplar mais elevado de arte dramática, atribuindo aos melodramas, às farsas e às operetas o rês do chão do estilo. Não se é de estranhar que aquele ator - a cuja companhia, aliás, a corte dera uma duradoura subvenção financeira - , preferira não se ver atrelado ao gênero cômico.

10 Os demais anúncios denominam-no, como no francês, "peça em 4 atos e 6 quadros". Cf. Teatro, 1846a, p. 2. 
Caberia à "Companhia Dramática de João Caetano" organizar, ainda, uma segunda récita de Robert Macaire, em 1849. O palco do evento seria, então, o "Teatro de S. Januário", que naquela ocasião recebia a "Compagnie Lyrique Française" - a qual, conforme apontamos, encenou, naquele ano, a versão em dois atos de L'Auberge des Adrets. ${ }^{11} \mathrm{~A}$ orientação musical da companhia francesa acaba influenciando a brasileira, a qual inscreve a peça no interior de um programa repleto de joie de vivre. Além de Robert Macaire - agora classificada como "comédia" - , o programa compõe-se da abertura da ópera de Meyerbeer Robert le diable; de um terceto da ópera de Rossini Guilherme Tell, de números de dança e de um vaudeville em um ato (Companhia, 1849, p. 4). A aproximação entre os repertórios de ambas as companhias ocorreu, quiçá, devido à ausência de João Caetano do Rio de Janeiro - o ator, então, realizava uma breve turnê na Bahia - ficando a personagem de Macaire a cargo do colega Augusto.

Os deslizamentos aos quais L'Auberge des Adrets e Robert Macaire foram submetidos, nos palcos cariocas - a exemplo do que ocorrera na França - , ratificam a incontornável relevância do âmbito da encenação na construção dos sentidos das obras teatrais. Não menos importantes são as questões de ordem prática referentes às trupes, aos teatros onde se encenavam as peças e ao contexto histórico contemporâneo às récitas. Tais questões - que a história do teatro, voltada exclusivamente para a dramaturgia do texto, deixou de lado por acessórias - enformam os sentidos das peças, como estamos procurando demonstrar neste artigo.

Esses elementos todos convergem para na inopinada interrupção às andanças de Robert Macaire, no Rio de Janeiro de 1858. Quatro anos após a récita da versão em 2 atos de L'Auberge des Adrets encenada pela "Ancienne Compagnie Française", - Teatro Ginásio Dramático submete ao "Conservatório Dramático Brasileiro" uma tradução do texto original da peça, o "drama em 3 atos A Estalagem dos Trampolineiros" - espetáculo censurado, em comum acordo, pelos dois pareceristas da casa aos quais coubera sua avaliação.

Os textos dos pareceres proibitórios deslindam, em complexidade, como se configurava a cena teatral do período. Demonstram, sobretudo, que os sentidos da obra não se limitam às linhas de sua dramaturgia. Submetida ao Conservatório sob a classificação de "drama", pela companhia que, batizada segundo o "Gymnase Dramatique" de Paris, procurava levar à cena a nova dramaturgia realista de moldes franceses, esta tradução de L'Auberge des Adrets aparentemente buscava fazer ecos aos esforços dos dramaturgos da capital visando-se a alinhar o gosto brasileiro ao moderno repertório francês.

Isto posto, há que se tecer alguns comentários acerca da escolha desta peça em específico. O teatro realista francês buscava escoimar-se dos arroubos do gênero melodramático, em direção a uma moralidade de cunho burguês, defensora da propriedade privada, da família e da hierarquia social. Trazido para o Brasil, o gênero procurava refletir sobre a realidade nacional - José de Alencar cooperou com sua pena aos esforços do grupo, aos quais produziu obras como O Demônio Familiar (1857) e As Asas

11 A distância entre as representações da peça em francês e da peça em português é de duas semanas. A récita de L'Auberge des Adrets ocorreu em 14 de julho de 1849, a de Robert Macaire, em 2 de agosto de 1849. Cf. Compagnie, 1849, p. 4; Companhia, 1849, p. 4. 
de um Anjo (1858). É curioso, neste sentido, que o Ginásio Dramático carioca tenha escolhido, para cooperar com este esforço de renovação, justamente um melodrama.

A tradução de L'Auberge des Adrets ao português, com o objetivo de ser encenado pelo Teatro Ginásio Dramático, aponta, por um lado, que aquele teatro fazia representar um repertório muito mais variado do que supõe a crítica tradicional do teatro brasileiro - a qual estabelece uma diferenciação estrita entre o repertório realista e o melodramático, considerando, o primeiro, um esforço notável de "elevação" da cena nacional, e o segundo, um gênero espúrio, voltado ao divertimento das classes populares (Faria, 2001). Ao atrelar a peça aos cânones do "drama", o tradutor brasileiro ratificava a miscigenação de estilos ocorridas, na época, na Europa - e, de roldão, no Brasil. No incontornável Mélodramatiques (2009), Jean-Marie Thomasseau demonstra que a incorporação do rótulo de "dramas" por parte dos melodramaurgos, se por um lado sublinhava a tentativa desses homens de se livrarem da visada preconceituosa voltada ao gênero popular no interior do qual trabalhavam, igualmente apontava para as semelhanças existentes, então, entre os procedimentos estilísticos inerentes ao gêneros "dramático" e "melodramático".

Os pareceres proibitórios à Estalagem dos Trampolineiros deslindam aspectos importantes da cena carioca de meados do XIX. Para além da dramaturgia do texto, atentava-se à relevância do teatro enquanto mecanismo de educação do espectador segundo a moral burguesa. De acordo com a folha de rosto do formulário de submissão dos textos ao Conservatório, seriam censuradas as obras que pecassem "contra a veneração à Nossa Santa Religião, contra o respeito devido aos Poderes Políticos da Nação e as Autoridades constituídas, e contra a guarda da moral e decência pública" (Biblioteca Nacional, 1858). Datada de agosto de 1845, tal medida é contemporânea à fundação do Conservatório.

Os brasileiros mantinham-se atualizados com relação ao contexto francês, de onde importavam, num só tempo, bens de consumo e bens culturais - como exemplo, as companhias francesas que encenaram, no Rio, L'Auberge des Adrets em 1840, 1849 e 1854. Sabiam, portanto, da celeuma provocada pela peça em Paris, onde ela ficou proibida nos momentos mais patentes de conflagração social. O repúdio da censura francesa à peça é, aliás, tomado como justificativa a priori para a censura brasileira, por parte do primeiro censor.

depois de muito apreciado pelo povo francês, que concorreu em massa aos teatros, a polícia, reconhecendo quão subversivas e perigosas eram as doutrinas aí apregoadas, proibiu a sua representação, e nunca mais, que me conste, subiu à cena em França semelhante drama (Conservatório, 1858, p. 2-3).

Um conhecimento contextual faz-se relevante: a França vinha, então, de debelar um movimento político de cunho socialista. Os dois pareceres à Estalagem dos Trampolineiros resvalam preocupação de que qualquer iniciativa desta ordem ocorresse em solo nacional. Teme-se, segundo esses textos, que ações de Robert Macaire como a crítica à hierarquia social e o repúdio ao ato indissolúvel do casamento sejam mimetizadas pelo seu público carioca.

A personagem de Macaire é partidária da redistribuição de posses, buscando, sem rebuços, servir-se daquilo que pertence ao alheio. Ademais, a obra coloca em 
questionamento os liames matrimoniais, os quais Macaire ironiza e Maria lamenta (já que fora obrigada a manter-se incontornavelmente unida ao homem que a desonrara): referindo-se à esposa que abandonara, Macaire afirma - cita textualmente o censor - que "se descartara de semelhante naipe há 18 ou 19 anos para subtrair-se a pequenas perseguições judiciárias"; ao passo que Maria considera o cônjuge "um monstro que perturba o descanso de sua vida" (Conservatório, 1858, p. 2-3). O segundo parecerista é enfático:

Temendo, pois, com justa razão, que o mesmo espírito de imitação que já vai produzindo em Portugal o mal que lamentamos, aclimate entre nós as subversivas ideias da inculcada escola regeneradora; temendo que o amor da liberdade, tão natural ao nosso coração, mal compreendendo o perigo dos princípios socialistas, os beba, principalmente nos romances e no teatro; não podemos deixar de protestar altamente contra os escritos que mostram tendência para tão terrível seita [...]. (Conservatório, 1858, p. 2-3)

\section{Conclusões}

Teceremos alguns apontamentos finais que dizem respeito aos eixos deste trabalho, quais sejam, a interpenetração dos gêneros e a relevância de elementos extra-textuais para a efetivação da obra dramática. L'Auberge des Adrets foi escrito segundo os cânones do melodrama: punindo-se no desfecho o cínico Robert Macaire - morto pela bala do comparsa - , e elevando-se à felicidade e à liberdade a esposa Marie, merecedora de tais benesses por ter purgado, em vida, pelos crimes cometidos pelo marido. A cena modular é, no entanto, subvertida graças à audácia de Frédérick Lemaître, que, ao imprimir carisma à personagem do vilão, rompeu com a fixidez inerente ao melodrama - questionando, por consequência, o papel pedagógico atribuído até então ao gênero.

Uma vez que o vilão caíra nas graças da "massa" francesa que ia ao teatro como bem lembra o parecerista brasileiro -, o público não mais tremeria diante de si. Em solo carioca, Macaire torna-se uma personagem celebrada, por exemplo, nos festejos carnavalescos e nas folhas ilustradas. É de se compreender que L'Auberge des Adrets tenha tido sua carreira proibida, no Rio, tão logo tenha ganho uma versão em português - as representações em francês tinham um público muito mais restrito, devido às limitações impostas pela língua.

Por fim, e não menos importante, há que se considerar o papel do drama burlesco Robert Macaire: que ressuscita o vilão e dá-lhe foros de herói, e o liberta, na fuga final, das amarras com o espaço, deixando-o livre para desdenhar do status quo. Este desdobramento de Robert Macaire, embora extra-diegético, foi fundamental para a proibição de A Estalagem dos Trampolineiros em solo carioca. A argumentação do primeiro censor fala por si:

O vício não deve prestar-se a figurar como elemento cômico, desde que não for fulminado, passo a passo, com as armas da razão, da justiça e da virtude. O procedimento contrário dá a sanção da imoralidade, e conduz ao recalcamento das leis sociais as quais cumpre acatar e respeitar sempre, sob pena de controverter os princípios de ordem, que têm ligação absoluta com a marcha progressiva da civilização (Conservatório, 1858, p. 2-3). 
Assim, ao tomarmos como exemplo a trajetória do melodrama L'Auberge des Adrets pelos palcos parisienses e cariocas, ao longo da primeira metade do século XIX, a partir de uma abordagem histórica interessada nas condições concretas da atividade teatral, que alarga o campo de investigação para além da relação texto/dramaturgo, pudemos enriquecer o campo de discussão em torno do gênero melodrama. Desse modo, L'Auberge des Adrets não se reduz a um melodrama de composição exagerada e de inverossimilhanças, pertencente a um gênero dramático considerado, pejorativamente, menor e que teria sido nocivo ao nascimento da dramaturgia brasileira no século XIX. Como tentamos expor, os gêneros dramáticos não são estanques e compartimentados segundo tempos cronológicos fixos de escolas literárias, como prova essa emblemática peça francesa, que, pelo jogo da cena e a participação do público, cambiou-se de um drama de lágrimas a um drama de riso subversivo.

\section{Referências}

ANTIER, Benjamin; SAINT-AMANT \& PAULYANTHE. A Estalagem dos Trampolineiros: Melodrama de Grande Espetáculo em Três Atos. Tradução, apresentação e notas de Danielle Crepaldi Carvalho e Bruna Grasiela Silva Rondinelli. São Paulo: Penalux, 2015.

AZEVEDO, Álvares de. Carta sobre a atualidade do teatro entre nós. In: Obras de M. A. Álvares de Azevedo. Tomo Terceiro: Obras Inéditas. 2. ed. Rio de Janeiro: Livraria de B. L. Garnier, 1862, p. 149-153.

BAPTISTA, Abel Barros. O cânone como formação: A teoria da literatura brasileira de Antonio Candido. In: O livro agreste: Ensaio de Curso de Literatura Brasileira. Campinas, SP: Editora da Unicamp, 2005, p. 41-80.

BARA, Olivier. Le rire subversif de Frédérick Lemaître / Robert Macaire, ou la force comique d'un théâtre d'acteur. Insignis - revue d'études littéraires et transdisciplinaires sur le XIXe siècle, n. 1, p. 9-23, mai. 2010. Disponível em: http://s1.e-monsite. com/2010/06/01/84165146insignis-numero-1-trans-e-complet-pdf.pdf. Acesso em: 9 set. 2015.

BERNARDET, Jean-Claude. Historiografia clássica do cinema brasileiro. 3. ed. São Paulo: Annablume, 2004.

BIBLIOTECA NACIONAL - Conservatório Dramático Brasileiro. Documento I - 08, 15, 21. Parecer n. 144 - A Estalagem dos Trampolineiros, 1858.

BRANDÃO, Tania. As lacunas e as séries: padrões de historiografia nas "Histórias do Teatro no Brasil". In: MOSTAÇO, Edélcio (Org.). Para uma História Cultural do Teatro. Florianópolis / Jaraguá do Sul: Design Editora, 2010, p. 333-375.

CANDIDO, Antonio. Formação da Literatura Brasileira: momentos decisivos. 2 Vols. 5. ed. 
São Paulo: Editora da Universidade de São Paulo, Editora Itatiaia Limitada, 1975 [1959].

CANDIDO, Antonio; CASTELO, José Aderaldo. Presença da Literatura Brasileira: história e crítica. 3 Vols. 7. ed. São Paulo: Difel, 1976 [1964].

COMPAGNIE Lyrique Française. Correio Mercantil, Rio de Janeiro, 13 jul. 1849, p. 4.

COMPANHIA Dramática de João Caetano. Correio Mercantil, Rio de Janeiro, 2 ago. 1849, p. 4.

CONSERVATÓRIO Dramático Brasileiro. Diário do Rio de Janeiro, Rio de Janeiro, 19 jul. 1858, p. 2-3.

FARIA, João Roberto. Ideias teatrais: O século XIX no Brasil. São Paulo: Perspectiva: Fapesp: 2001.

. O lugar da dramaturgia nas histórias da literatura brasileira. Sala Preta,

São Paulo, v. 10, p. 9-25, 2010.

GAZETILHA. Jornal do Recife, Recife, 8 jan. 1888, p. 2.

HOUAISS Eletrônico. Versão monousuário 3.0, jun. 2009. 1 CD-ROM.

JUNQUEIRA, Christine. Histórias globais do teatro: novas perspectivas para a historiografia. Sala Preta, São Paulo, v. 15, p. 238-248, 2015.

KRAKOVITCH, Odile. Robert Macaire ou la grande peur des censeurs. Europe - revue littéraire mensuelle, Paris, n. 703-704, p. 49-60, nov.-déc./1987.

L'AUBERGE DES ADRETS - Robert Macaire - M. Moreau. Diário do Rio de Janeiro, Rio de Janeiro, 14 nov. 1840, p. 4.

LEMAITRE, Frédérick. Souvenirs. Paris: P. Ollendorff, 1880.

MM. BENJAMIN, SAINT-AMANT; PAULYANTHE [Maurice Alhoy]. L'Auberge des Adrets: drame en trois actes à spectacle. Paris: Pollet - Libraire-Éditeur de Pièces de Théâtre, 1823.

L'Auberge des Adrets: drame en trois actes, à spectacle. Représenté pour la première fois, à Paris, sur le théâtre de l'Ambigu-Comique, le 2 juillet 1823 et repris sur le théâtre de la Porte Saint-Martin, le 28 janvier 1832. Paris: Imprimerie Normale de Jules Didot L'Ainé, 1832.

MM. SAINT-AMAND, ANTIER et FRÉDÉRIC LEMAITRE. Robert Macaire: pièce en quatre actes et en six tableaux. In: La France Dramatique au Dix-Neuvième Siècle: Porte St. Martin. Paris: Bureau de la France Pittoresque (J. N. Barba: Delloye: Bezou), 1835. 
MORETTIN, Eduardo. Acervos Cinematográficos e Pesquisa Histórica: Questões de Método. Revista Esboços, Florianópolis, v. 21, n. 31, p. 50-67, ago. 2014. Disponível em: https://goo.gl/xb5l6e. Acesso em: 25 ago. 2015.

NAUGRETTE, Florence. Le Théâtre Romantique : Histoire, écriture, mise en scène. Paris: Seuil, 2001.

PRADO, Décio de Almeida. História Concisa do Teatro Brasileiro. São Paulo: EDUSP, 1999.

SOUSA BASTOS, Antonio. Diccionario do Theatro Portuguez. Lisboa: Imprensa Libanio da Silva, 1908.

SOUZA, Silvia Cristina Martins de. As Noites do Ginásio: Teatro e tensões culturais na corte (1832-1868). Campinas, SP: Editora da UNICAMP, CECULT, 2002.

TEATROS. Diário do Rio de Janeiro, Rio de Janeiro, 22 ago. 1839, p. 3.

TEATRO. Diário do Rio de Janeiro, Rio de Janeiro, 6 nov. 1846, p. 2 [1846a].

TEATRO. Diário do Rio de Janeiro, Rio de Janeiro, 10 nov. 1846, p. 2 [1846b].

THOMASSEAU, Jean-Marie. Drame et Tragédie. Paris: Hachette, 1995.

Mélodramatiques. Vincennes: Presses Universitaires de Vincennes;

Saint-Denis: Université Paris 8, 2009.

Recebido em: 21/09/2015

Aprovado em: 08/02/2016 